\title{
Juliana Lopoukhine, Frédéric Regard, and Kerry- Jane Wallart, eds., Transnational Jean Rhys. Lines of Transmission, Lines of Flight
}

Pauline Amy de la Bretèque

\section{(2) OpenEdition}

\section{Journals}

Electronic version

URL: https://journals.openedition.org/ces/7644

DOI: $10.4000 /$ ces.7644

ISSN: 2534-6695

Publisher

SEPC (Société d'études des pays du Commonwealth)

Electronic reference

Pauline Amy de la Bretèque, "Juliana Lopoukhine, Frédéric Regard, and Kerry-Jane Wallart, eds. Transnational Jean Rhys. Lines of Transmission, Lines of Flight", Commonwealth Essays and Studies [Online], 43.2 | 2021, Online since 23 July 2021, connection on 02 February 2022. URL: http:// journals.openedition.org/ces/7644 ; DOl: https://doi.org/10.4000/ces.7644

This text was automatically generated on 2 February 2022

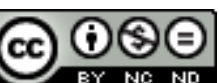

Commonwealth Essays and Studies is licensed under a Licence Creative Commons Attribution - Pas d'Utilisation Commerciale - Pas de Modification 4.0 International. 


\title{
Juliana Lopoukhine, Frédéric Regard, and Kerry-Jane Wallart, eds., Transnational Jean Rhys. Lines of Transmission, Lines of Flight
}

\author{
Pauline Amy de la Bretèque
}

\section{REFERENCES}

Juliana Lopoukhine, Frédéric Regard, and Kerry-Jane Wallart, eds. Transnational Jean Rhys. Lines of Transmission, Lines of Flight. New York: Bloomsbury, 2020. 210 p. ISBN (hb): $9781501361296 . £ 80$

1 Situating Jean Rhys as a writer has always been challenging, owing to her ambiguous position as a white Creole and as a Caribbean migrant in Europe, but also to her marginalisation among modernist and postcolonial authors. The readings of Rhys's texts have long been restricted exclusively to their feminine dimension, or to a modernist perspective, or to a postcolonial interpretation. Only recently have critics argued for a perspective across the critical spectrum, without trying to fit the author into one category only (Carr 2012). This volume promotes a reading of Rhys's works across categories, building upon transversal theoretical approaches like transnationalism, transculturalism, or diasporic studies. Along the same lines as other critical studies of Rhys based on an intertextual reading (Johnson 2003), Transnational Rhys: Lines of Transmission, Lines of Flight explores the transnational passages that give Rhys's fiction its hybrid and unclassifiable shape. It brings new perspectives to Jean Rhys's work, showcasing the multicultural influences that penetrate her writing and which have been largely overlooked by critics. Regarding Rhys as a "diasporic visionary" (3), the volume thus redefines Glissant's notion of creolization (1990) as "an ability to absorb and translate" (6) beyond the borders of the Caribbean. 
2 The essays contained in this volume were presented during the first international Jean Rhys conference organized in Paris - a city where Rhys lived and that mattered to her in 2018 by Juliana Lopoukhine, Frédéric Regard and Kerry-Jane Wallart. The essays explore Jean Rhys's international connections beyond the binary opposition between her British and Caribbean identities. Each chapter engages in transcending the opposition between England and Dominica, focusing on the broader international influences that had an impact on Rhys's writing, such as her trips to the Caribbean and within Europe, her interest in French literature and translation, or her critique of various forms of imperialism across the globe, from America to Japan, and Indonesia. The editors argue against the isolationism that is sometimes attributed to Rhys, since she was indeed deeply influenced by French literature, but also because of the considerable influence she has had on many other writers.

3 The eleven essays published in this collection are divided into two sections. The first one tackles the influences to which Rhys was exposed while in Paris, and examines how these connections can be considered as a starting point of Rhys's constant transcultural mobility. The chapters of this first section weave original parallels between Rhys and other literary or cultural figures, such as Hemingway, Joyce, Rimbaud, Colette, Marc Bloch but also Joséphine de Beauharnais. They offer comparative readings of Rhys along with other authors, sometimes suggesting the influence that they might have had on her writings and on her use of autobiography in her fiction, but also trying to situate Rhys in relation to various literary circles. Some of these parallels give unprecedented perspectives on her writing, considering for instance, as Christopher GoGwilt does, the impact of her personal interest in Indonesia on her fiction. Such approaches significantly challenge familiar readings of her texts: Scott McCracken thus interprets Rhys's fiction through a comparison with Marc Bloch's historical memoir, an approach which allows us to consider Rhys as a historian rather than a novelist, and her protagonists as defeated women rather than victims. One might think that the parallels drawn in the first section sometimes are far-fetched, or distant, as it were, though we may argue that they explore new aspects of Rhys's fiction, thus offering a groundbreaking and rhizomatic perspective on its relation to a globalized and creolized world.

4 The second section deals with the influence of Rhys on other writers across the world. Sue Thomas, for instance, presents an original analysis of the influence of Wide Sargasso Sea on Australian neo-Victorian fiction and more particularly on adaptations of Jane Eyre for opera, the stage, television or cinema. This section pays particular attention to intertextual connections between Rhys and other writers, such as Brathwaite or Jamaica Kincaid, suggesting how Rhys's fiction may have inspired these writers in the way of tackling the fragmentation of Caribbean identity, or in the use of clothing or "self-fashioning" (127) as a political instrument of self-definition. The last three chapters are devoted to Caryl Phillips, and more precisely to his novel A View of the Empire at Sunset (2018), a fictional biography of Rhys. They examine the complex overlapping of fiction and non-fiction and Phillips's questioning of the generic boundaries between novel and biography.

5 The collection skilfully draws to a close with an interview of Caryl Phillips by KerryJane Wallart, in which he evokes his creative approach in writing A View of the Empire at Sunset. He retraces his readings and his visits to Paris and Dominica where he followed in Rhys's footsteps. Phillips expands the reflection initiated in the preceding chapters on the nature of the autobiographical genre, which is in his view intrinsically fictional. 
Transnational Rhys thus develops an insightful and innovative analysis of Rhys's life and fiction by enlarging the geographical and theoretical scope of studies of her writings and regarding her as "one of the first truly diasporic writers of our postmodernity" (6).

\section{BIBLIOGRAPHY}

CARR, Helen. 2012. Jean Rhys. Horndon, Tavistock, Devon: Northcote House Publishers.

JoHnson, Erica. 2003. Home, Maison, Casa: The Politics of Location in Works by Jean Rhys, Marguerite Duras, and Erminia Dell'Oro. Madison, NJ: Farleigh Dickinson University Press.

GLISSANT, Edouard. 1997. Poetics of Relation. Translated by Betsy Wing. Ann Arbor: University of Michigan Press. Originally published as Poétique de la Relation (Paris: Gallimard, 1990).

\section{AUTHOR}

\section{PAULINE AMY DE LA BRETÈQUE}

Université Sorbonne Nouvelle

Pauline Amy de la Bretèque holds a doctorate from Sorbonne University. Her PhD dissertation examines feminine poetics of creolisation in the works of Jean Rhys, Paule Marshall, Olive Senior, Jamaica Kincaid and Michelle Cliff. She has co-organized a conference on Caribbean literary landscapes and ecocriticism in 2019 and has published several articles on Caribbean literature. Her publications include "Textes rhizomes et créolisation chez Jean Rhys et Michelle Cliff" in Edouard Glissant, l'éclat et l'obscur (Presses Universitaires des Antilles, 2020) and "Memorial Excursion and Errancy in Paule Marshall's Praisesong for the Widow" in Babel. Littératures Plurielles 40 (2019). 